\title{
Induction of Methanethiol Production by Brevibacterium linens CNRZ 918
}

\author{
By M. FERCHICHI, * D. HEMME AND MICHÈLE NARDI \\ Laboratoire de Microbiologie Laitière, Institut National de la Recherche Agronomique, Centre de \\ Recherches de Jouy-en-Josas, 78350 Jouy-en-Josas, France
}

(Received 26 March 1986)

A non-inducing medium (NID) was defined for studying the induction of methanethiol production by Brevibacterium linens CNRZ 918. The lowest $\mathrm{L}$-methionine concentration capable of inducing maximal methanethiol production by the cells was $7 \mathrm{mM}$. The peptides L-Ala-L-Met and L-Met-L-Ala induced greater methanethiol production than free L-methionine. DMethionine, L-cysteine, $S$-methyl-L-cysteine and L-ethionine were poor inducers. Culture temperature affected the duration of induction. An $\mathrm{Na}^{+}$concentration of $1 \mathrm{M}$ in the culture medium led to maximal methanethiol production capacity of both cells and cell extracts. LMethionine and L-ethionine were the best substrates for the crude soluble cells extract (with release of methanethiol and ethanethiol respectively). Neither the derivatives of L-methionine that acted as inducers, nor D-methionine, were substrates for demethiolation. Demethiolation activity of the crude extract was thermolabile, not stimulated by $\mathrm{Na}^{+}$and strongly inhibited by $\mathrm{Zn}^{2+}, \mathrm{Mn}^{2+}$ and $\mathrm{Cu}^{2+}$. The shortest generation time obtained for $B$. linens CNRZ 918 in NID medium $+\mathrm{L}$-methionine was $4 \mathrm{~h}$ at $26^{\circ} \mathrm{C}$. Only coccoid forms were present when the culture temperature was $30^{\circ} \mathrm{C}$. The presence of $\mathrm{L}$-methionine in the medium favoured their appearance. The strain grew best in the presence of $1 \% \mathrm{NaCl}$ but tolerated concentrations up to $15 \%$. The induction of methanethiol production was due to the induction of $L$-methionine- $\gamma$-demethiolase. The level of induction was probably related to the intracellular concentration of $\mathrm{L}$-methionine. The transport system of L-methionine by $B$. linens CNRZ 918 was constitutive and $\mathrm{Na}^{+}$ dependent.

\section{INTRODUCTION}

Some cheeses, for instance the French varieties Pont l'Evêque, Munster, Livarot, Vacherin and Camembert, exhibit charcteristic flavours (see Ferchichi et al., 1985) attributable to sulphur compounds which arise from the condensation of precursors such as $\mathrm{CH}_{3} \mathrm{SH}$ and $\mathrm{H}_{2} \mathrm{~S}$ (Law, 1984). The thiols, in particular methanethiol, are produced by the predominant surface rind flora of these orange-coloured smear-ripened cheeses, which is mainly composed of bacteria related to Brevibacterium linens (Richard, 1984).

Methanethiol production from methionine in various organisms was reviewed by Kadota \& Ishida (1972). Since that time, studies have been done with Pseudomonas spp. (Ito et al., 1976; Laakso et al., 1976; Tanaka et al., 1977; Laakso \& Laukkanen, 1982), Clostridium sporogenes (Kreiss \& Hession, 1973), coryneform bacteria (Sharpe et al., 1977; Ferchichi et al., 1985) and rumen bacteria (Merricks \& Salsbury, 1975). Several demethiolases have been purified, sometimes partially, e.g. from Pseudomonas spp. (Tanaka et al., 1976; Ito et al., 1976; Tanaka et al., 1977, 1985; Esaki et al., 1977; Nakayama et al., 1984b), Aeromonas sp. (Nakayama et al., $1984 a$ ) and Aspergillus sp. (Ruiz-Herrera \& Starkey, 1969). Only the enzyme of $C$. sporogenes (EC 4.4.1.11) has been fully characterized (Kreiss \& Hession, 1973). The inducible character of

Abbreviations: DTNB, 5,5'-dithio-bis-2-nitrobenzoic acid; NID, non-inducing medium (for demethiolation); sMTPC, specific methanethiol-producing capacity. 
methanethiol production has been reported by relatively few authors, with no attempt to characterize this induction. The present work describes the induction of methanethiol production by $B$. linens CNRZ 918 and the factors which can affect production.

\section{METHODS}

Strain and culture media. Brevibacterium linens CNRZ 918 was the strain used in our previous study (Ferchichi $e t$ al., 1985). The basic non-inducing medium used (NID) had the following composition $\left(\mathrm{g} \mathrm{l}^{-1}\right)$ : sodium DL-lactate (Sigma) 5·0, yeast extract (Difco) $1 \cdot 0$, peptone (Bio-case low salt, Mérieux, Marcy l'Etoile, France) $1 \cdot 0$, L-alanine (Sigma) 5.0, $\mathrm{K}_{2} \mathrm{HPO}_{4} 1.7, \mathrm{KH}_{2} \mathrm{PO}_{4} 0.24, \mathrm{CaCl}_{2} 0.025, \mathrm{MgSO}_{4} .7 \mathrm{H}_{2} \mathrm{O} 0.2, \mathrm{NaCl} 10$. This basic medium was supplemented with L-methionine (Sigma) at $1.0 \mathrm{~g} \mathrm{l}^{-1}$ (NID + L-methionine) or with analogues. After inoculation, the NID (unsupplemented) medium contained $0.3 \mathrm{mM} \mathrm{L}$-methionine from the carryover. The final $\mathrm{pH}$ of the medium varied from 7.5 to 7.3 and decreased by 0.2 unit after autoclaving for 20 min at $120^{\circ} \mathrm{C}$. The final $\mathrm{Na}^{+}$ concentration in NID + L-methionine was $5 \mathrm{~g}^{-1}$.

Cultures. One $\mathrm{ml}$ of the culture, prepared as previously described (Ferchichi et al., 1985), was used to inoculate the preculture $\left(100 \mathrm{ml}\right.$ of NID + L-methionine in a $500 \mathrm{ml}$ Erlenmeyer flask), which was grown at $26^{\circ} \mathrm{C}$ with shaking for $70 \mathrm{~h}$. This preculture was then used to inoculate (1-2\%) the experimental culture. Experimental cultures were similarly grown in $1000 \mathrm{ml}$ capacity Erlenmeyer flasks filled to $20 \%$ capacity and shaken at 100 cycles $\min ^{-1}$ in a water-bath reciprocal shaker.

Amino acid analysis in culture medium. Samples $(3 \mathrm{ml})$ of culture medium were removed at the times indicated. After centrifugation $(12500 \mathrm{~g}, 20 \mathrm{~min})$ the supernatant was aseptically filtered ( $200 \mathrm{~nm}$ pore size) and then diluted in $100 \mathrm{mM}$-citrate buffer $\mathrm{pH} 2 \cdot 2$ containing $120 \mathrm{mM}-\mathrm{Na}^{+}$. This solution was analysed with a Biotronick LC5000 automatic amino acid analyser.

Preparation of crude extracts. After $24 \mathrm{~h}$ growth in NID + L-methionine, cells were harvested by centrifuging at $12500 \mathrm{~g}$ for $10 \mathrm{~min}$ at $4^{\circ} \mathrm{C}$. The pellet was suspended $\left(\mathrm{OD}_{650}=50\right)$ in $100 \mathrm{mM}-\mathrm{Tris} / \mathrm{HCl}, \mathrm{pH} 8 \cdot 5$, containing 0.5 mM-pyridoxal 5'-phosphate (Sigma), $0.05 \mathrm{~mm}$-2-oxobutyrate (Sigma) and $1 \mathrm{~mm}-\mathrm{CaCl}_{2}$ (Prolabo) as stabilizing agents. The cells were broken by ultrasonic treatment (Ultrasonic NSU157 at $60 \%$ of full power, $600 \mathrm{~mA}$ ) of $5 \mathrm{ml}$ of the suspension for five $1 \mathrm{~min}$ periods, each followed by a resting period of $2 \mathrm{~min}$ in an ice-water bath. The crude extract was centrifuged at $12500 \mathrm{~g}$ for $10 \mathrm{~min}$ at $4{ }^{\circ} \mathrm{C}$ and the supernatant $\left(1.5-2.0 \mathrm{~g}\right.$ protein $\left.1^{-1}\right)$ constituted the crude soluble extact. To study the effect of metal ions, the extract was dialysed against $100 \mathrm{~mm}$-Tris/ $\mathrm{HCl}, \mathrm{pH} 8.5$, containing $0.5 \mathrm{~mm}$-pyridoxal 5 -phosphate just before use. The protein concentration was determined by the method of Lowry with crystalline bovine serum albumin as reference.

Transport assays. Exponential phase cells (rod cells) and cells in the stationary growth phase (coccoid cells) were harvested by centrifugation at $12500 \mathrm{~g}$ for $20 \mathrm{~min}$ at $4{ }^{\circ} \mathrm{C}$. The cells were washed twice with $50 \mathrm{mM}$-Tris/ $\mathrm{HCl}$, $\mathrm{pH} 8$, and resuspended in the same buffer to give a final concentration of $1.2 \mathrm{mg}$ dry weight $\mathrm{ml}^{-1}$. After preincubation for $10 \mathrm{~min}$ at $30^{\circ} \mathrm{C}$ with shaking $\left(120\right.$ strokes $\left.\mathrm{min}^{-1}\right)$, the reaction was started by the addition of $\mathrm{L}$ $\left[3,4^{-14} \mathrm{C}\right]$ methionine (final concn $100 \mu \mathrm{M}$ ) (purchased from the Commissariat á l'Energie Atomique, Saclay, France; final specific radioactivity in the test tube $27.4 \mathrm{MBq} \mathrm{mol}^{-1}$ ). After $15 \mathrm{~s}, 45 \mathrm{~s}$ and $90 \mathrm{~s}, 200 \mu \mathrm{l}$ of the reaction mixture was removed and rapidly filtered through a membrane filter ( $450 \mathrm{~nm}$ pore size, HA, Millipore). The residues on the filter were washed twice with $4 \mathrm{ml}$ of the same buffer at $30^{\circ} \mathrm{C}$. The filters were then dried under an infrared lamp and placed in scintillation vials containing $5 \mathrm{ml}$ Ready-solv Hp/b (Beckman). Radioactivity was determined with a liquid scintillation spectrometer (Beckman LS90000) with a counting efficiency better than $95 \%$ for ${ }^{14} \mathrm{C}$. The initial rate of transport ( $v_{\mathrm{i}}$, expressed in nkat per $\mathrm{g}$ cell dry weight) was estimated from the slope between $0 \mathrm{~min}$ and $1 \mathrm{~min}$.

Methanethiol production capacity (MTPC) of harvested resting cells and crude extacts. The MTPC of harvested resting cells was determined as previously described (Ferchichi et al., 1985) using DTNB (5,5'-dithio-bis-2nitrobenzoic acid), which reacts with the thiols formed by the action of the L-methionine- $\gamma$-demethiolase (Laakso \& Nurmikko, 1976; Law \& Sharpe, 1978). The substrates tested were from Sigma. The calibration curves were linear with methanethiol (up to $250 \mu \mathrm{M}$ ) and ethanethiol (up to $60 \mu \mathrm{M}$ ). An $A_{412}$ value of 1.0 in a $1 \mathrm{~cm}$ light path cuvette corresponded to $220 \mu \mathrm{M}$-methanethiol or $46 \mu \mathrm{M}$-ethanethiol.

The specific methanethiol producing capacity (sMTPC) of the cells were defined as nmol methanethiol produced $\mathrm{s}^{-1}(\mathrm{~g} \text { dry wt of cells) })^{-1}$ [nkat (g dry wt) $)^{-1}$ or nmol s-1 $\mathrm{g}^{-1}$ ] from the substrate under the conditions of the assay, and the SMTPC of the extracts as mkat ( $\mathrm{kg}$ protein $)^{-1}$.

The method of Laakso \& Nurmikko (1976) was adapted for the extracts. The reaction medium (total volume $0.6 \mathrm{ml}$ in a semi-micro cuvette) contained (final concn) $100 \mathrm{~mm}$-Tris/HCl, pH 8.5, 0.2 mM-DTNB (dissolved in ethanol), substrate (variable concn of L-methionine or analogues), $33 \mu \mathrm{M}$-pyridoxal phosphate, $3.35 \mu \mathrm{M}-2$ oxobutyrate and $67 \mu \mathrm{M}-\mathrm{CaCl}_{2}$, both the latter being derived from the crude extract. After the addition of $40 \mu \mathrm{l}$ extract (containing $\sim 5 \mu \mathrm{g}$ protein) methanethiol production at $30^{\circ} \mathrm{C}$ was followed at $412 \mathrm{~nm}$ with a Beckman 25 spectrophotometer. The rates were recorded for $2 \mathrm{~min}$ and the activity was calculated from the slope ( 70 pkat equivalent to $0 \cdot 1$ absorbance unit with cysteine as a reference). 


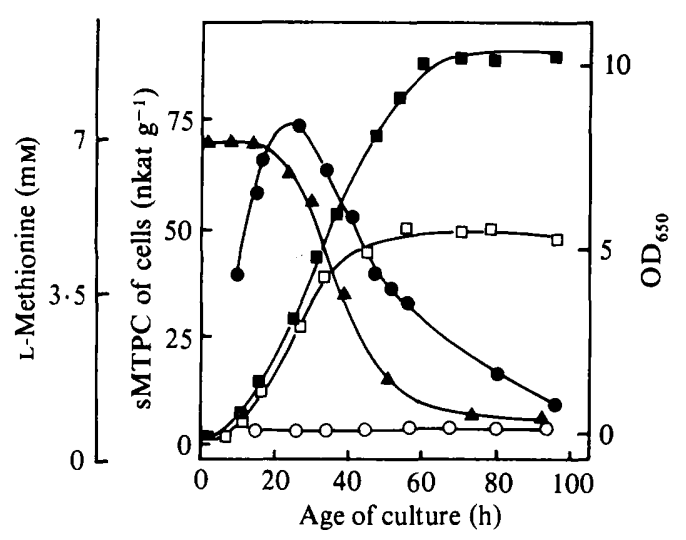

Fig. 1

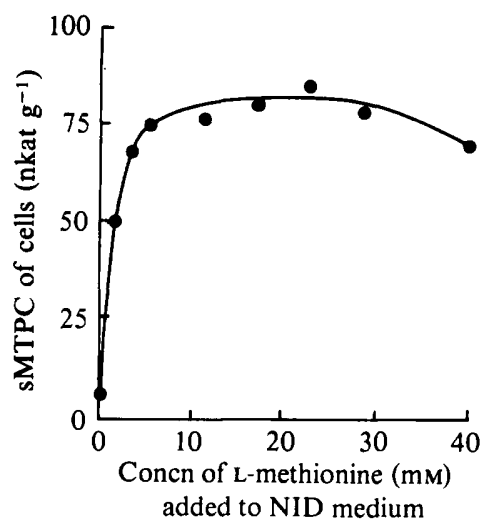

Fig. 2

Fig. 1. sMTPC of harvested cells $(\mathcal{O}, \mathrm{O})$, L-methionine concentration in the medium $(\boldsymbol{\Lambda})$ and $\mathrm{OD}_{650}$ $(\square, \square)$ of $B$. linens CNRZ 918 grown at $26^{\circ} \mathrm{C}$ in NID (open symbols) and NID + L-methionine (solid symbols).

Fig. 2. Effect of L-methionine concentration in NID medium on the sMTPC of $B$. linens CNRZ 918 grown at $26^{\circ} \mathrm{C}$.

Thermal inactivation. Crude extract $(0.5 \mathrm{ml})$ was placed in prewarmed glass test tubes $(6 \times 50 \mathrm{~mm})$ at $25^{\circ} \mathrm{C}$, $30^{\circ} \mathrm{C}, 35^{\circ} \mathrm{C}$ and $45^{\circ} \mathrm{C}$. At different times, samples $(40 \mu \mathrm{l})$ were removed, immediately cooled to $0{ }^{\circ} \mathrm{C}$ and tested for residual sMTPC.

Reproducibility. All the results presented are the mean of three or more replicate assays. The observed variations were consistently lower than $10 \%$.

\section{RESULTS}

Search for a non-inducing medium. Methanethiol production by $B$. linens grown in a complex medium tripled when the medium was supplemented with $0.1 \% \mathrm{~L}$-methionine (Ferchichi et al., 1985). It was thus highly probable that an induction phenomenon occurred. After investigating the growth and methanethiol production of the strain in various maximally defined media, we chose NID (see Methods) as a non-inducing medium. Although this medium was simpler than the culture medium used by Ferchichi et al. (1985), it was nevertheless necessary to add a low concentration of yeast extract and peptone (each to $0.1 \%$ ) to maintain an acceptable growth rate.

The sMTPC of cells grown in NID medium was very low (Fig. 1). The addition of Lmethionine to this medium (NID + L-methionine) increased the sMTPC 12-fold at the maximum obtained after $24 \mathrm{~h}$ growth. The transport of L-methionine by the cells grown on NID + L-methionine or on NID, as rod or coccoid forms, was the same (initial rate $9 \pm 2 \mathrm{nkat}^{-1}$ ). When sMTPC was maximum, $88 \%$ of the L-methionine remained in the NID + L-methionine medium. After this, its concentration decreased more rapidly, as it was a growth factor, resulting in twice as much growth as that obtained with NID medium (Fig. 1). The presence of L-methionine caused an earlier appearance of coccoid cells, which constituted the major cell form when the $\mathrm{OD}_{650}$ reached 3.5 in NID + L-methionine, as opposed to 5 in NID. Different forms, all able to divide, were observed by electron microscopy in an $18 \mathrm{~h}$ NID + L-methionine culture, as previously observed in the complex BM medium (Ferchichi et al., 1985). Compared to this complex BM medium, the maximum sMTPC of resting cells grown on NID + L-methionine was higher and earlier ( $24 \mathrm{~h}$ as opposed to $60 \mathrm{~h})$ and growth did not exhibit a latency period.

Optimal inducing concentration of $\mathrm{L}$-methionine. The addition of $\mathrm{L}$-methionine up to about $7 \mathrm{mM}$ to NID medium increased the SMTPC of the cells; higher concentrations did not increase the sMTPC further (Fig. 2). A final L-methionine concentration of $7 \mathrm{mM}(6.7 \mathrm{mM}$ or $0.1 \%$ added to 
Table 1. Specificity of induction of methanethiol production by B. linens CNRZ 918

Rod cells were harvested after $28 \mathrm{~h}$ growth at $26^{\circ} \mathrm{C}$ in NID medium $+6.7 \mathrm{~mm}$ inducer (except for the control) and their sMTPC from L-methionine was determined as described in Methods. The results are expressed relative to the value for cells from NID + L-methionine $\left(100 \%\right.$ or $\left.75 \mathrm{nkat}^{-1}\right)$.

Inducer added $(6.7 \mathrm{~mm})$

to NID medium

Control (no supplementation)

L-Methionine

D-Methionine

L-Ethionine

L-Cysteine

$S$-Methyl-L-cysteine

$S$-Ethyl-L-cysteine

Seleno-DL-methionine

DL-Methionine sulphoxide

2-Aminobutyric acid

2-Oxobutyric acid

2-Oxo-4-methiolbutyric acid

L-Methioninamide

$N$-Formyl-DL-methionine

$N$-Benzyl-L-methionine

Acetyl-L-methioninamide
Inducer added $(6.7 \mathrm{~mm})$

to NID medium

SMTPC (\%)

$\begin{array}{rlr}6 & \text { L-Met-L-Ala } & 153 \\ 100 & \text { L-Met-L-Gly } & 92 \\ 25 & \text { L-Met-L-Phe } & 81 \\ 17 & \text { L-Met-L-Asp } & 65 \\ 11 & \text { L-Met-L-Met-L-Met } & 77 \\ 16 & \text { L-Met-L-Arg-L-Phe-L-Ala } & 54 \\ 4 & \text { L-Ala-L-Met } & 150 \\ \text { NG } & \text { L-Ser-L-Met } & 99 \\ 8 & \text { L-Pro-L-Met } & 84 \\ 5 & \text { Gly-L-Met-Gly } & 100 \\ 5 & \text { L-Leu-L-Trp-L-Met-L-Arg } & 82 \\ 4 & \text { N-Formyl-L-Met-L-Ala } & 77 \\ 108 & \text { L-Trp-L-Met-L-Asp-L-Phenylalanyl- } & \\ 90 & \text { amide } & 28\end{array}$

NG, No growth.

the medium during preparation) was chosen for subsequent studies in NID + L-methionine (see Methods). Regardless of whether L-methionine $(6.7 \mathrm{~mm})$ was added initially to the culture medium or after $18 \mathrm{~h}$ incubation, the sMTPC obtained after about $24 \mathrm{~h}$ of incubation, i.e. $6 \mathrm{~h}$ after the delayed addition, was identical.

Specificity of induction. Various compounds related to methionine (structural analogues, methionine derivatives, methionine-containing peptides or potential degradation products) were tested for their inducing ability (Table 1). The dipeptides L-Ala-L-Met and L-Met-L-Ala gave a higher SMTPC in resting cells than did L-methionine alone. Variable induction was observed with other peptides or pseudopeptides. D-Methionine, L-cysteine, $S$-methyl-L-cysteine and L-ethionine were poor inducers although they were used as the sole carbon and nitrogen source for growth (M. Ferchichi, D. Hemme \& J. E. Baudoin, unpublished results). Neither degradation products nor $S$-ethyl-L-cysteine were inducers. Selenomethionine (S replaced by $\mathrm{Se}$ ) inhibited growth.

The sMTPC of crude extracts and the transport of L-methionine by the cells obtained from cultures on NID + one peptide (L-Ala-L-Met or L-Met-L-Ala or L-methioninamide or $N$-formylL-methionine) was the same as that of cells obtained from NID or NID + L-methionine.

Specificity of demethiolation. Demethiolating activity was present only in the soluble fraction of cell extracts. Stabilization of the activity was obtained with $500 \mu \mathrm{M}$-pyridoxal phosphate $\left(K_{\mathrm{m}}\right.$ value); maximal activity required $5 \mathrm{~mm}$ of this cofactor. This may explain the $40 \%$ loss of activity observed during dialysis. Only L-methionine $\left(K_{\mathrm{m}} 5 \mathrm{mM}\right)$, DL-methionine sulphoxide, $S$ methyl-L-cysteine and L-ethionine $\left(K_{\mathrm{m}} 5 \mathrm{mM}\right)$ were substrates (Table 2). In contrast to nonproliferating cells (Ferchichi et al., 1985), none of the peptides or other methionine derivatives were substrates for the soluble crude extract.

Influence of growth temperature on SMTPC of cells. The maximal sMTPC for cells grown in NID + L-methionine varied from $60 \mathrm{nkat} \mathrm{g}^{-1}$ for cells grown at $20^{\circ} \mathrm{C}$ to $75 \mathrm{nkat} \mathrm{g}^{-1}$ for cells grown at $26^{\circ} \mathrm{C}$. The $\mathrm{sMTPC}$ values decreased less rapidly on continued incubation at $20^{\circ} \mathrm{C}$ than at $26^{\circ} \mathrm{C}$ or $30^{\circ} \mathrm{C}\left(50 \%\right.$ of maximum reached $32 \mathrm{~h}$ after the maximum at $20^{\circ} \mathrm{C}$, compared to $21 \mathrm{~h}$ at $26^{\circ} \mathrm{C}$ or $30^{\circ} \mathrm{C}$ ). The optimal growth temperature in NID + L-methionine was $26^{\circ} \mathrm{C}$. The shortest latency time, the shortest generation time $(4 \mathrm{~h} \pm 15 \mathrm{~min}$, mean of 15 cultures $)$ and the 
Table 2. $s M T P C$ of crude extract of $B$. linens $C N R Z 918$ with respect to different substrates

Activity is expressed relative to that against $\mathrm{L}$-methionine $\left(100 \%\right.$ or $\left.12 \mathrm{mkat} \mathrm{kg}^{-1}\right)$. For comparison, values obtained with non-proliferating cells (Ferchichi et al., 1985) are given in parentheses.

\begin{tabular}{lrr} 
& \multicolumn{1}{c}{$\begin{array}{c}\text { Substrate } \\
(24 \mathrm{mM})\end{array}$} & \multicolumn{2}{c}{ sMTPC } \\
& $\%(\%)$ \\
L-Methioninamide & 0 & $(472)$ \\
L-Ala-L-Met & 0 & $(245)$ \\
L-Met-L-Ala & 0 & $(245)$ \\
L-Ethionine* & 123 & $(120)$ \\
L-Methionine (control) & 100 & $(100)$ \\
DL-Methionine & 77 & $(60)$ \\
S-Methyl-L-cysteine & 21 & $(40)$ \\
2-Oxo-4-methiolbutyric acid & 5 & $(38)$ \\
N-Formyl-DL-methionine & 0 & $(30)$ \\
DL-Methionine-S-methysulphonium chloride & 8 & $(17)$ \\
DL-Methionine-2-hydroxy analogue & 0 & $(11)$ \\
DL-Methionine sulphoxide & 21 & $(9)$ \\
D-Methionine & 0 & $(0)$ \\
DL-Methioninol & 5 & $(0)$
\end{tabular}

* In this case, ethanethiol was produced and the production capacity was estimated by comparison with a calibration graph obtained with ethanethiol instead of methanethiol.

Table 3. Effect of metal ions on methanethiol production from L-methionine by non-proliferating cells and crude extract of $B$. linens CNRZ 918 The results are expressed relative to demethiolating activity without added metal ions for dialysed crude
extract $\left(100 \%\right.$ or $\left.7.2 \mathrm{mkat} \mathrm{kg}^{-1}\right)$ and for non-proliferating cells $\left(100 \%\right.$ or $\left.75 \mathrm{nkat} \mathrm{g}^{-1}\right)$. Ions (all added as
chloride salts) were $1 \mathrm{~mm}$ for extract and $10 \mathrm{~mm}$ for cells. Cells were harvested after 24 hrowth in NID
medium + L-methionine.

$\begin{array}{lcc}\text { Ion } & \begin{array}{c}\text { sMTPC of } \\ \text { crude extract }(\%)\end{array} & \begin{array}{c}\text { sMTPC of } \\ \text { cells }(\%)\end{array} \\ \text { Control } & 100 & 100 \\ \mathrm{Na}^{+} & 92 & 200 \\ \mathrm{~K}^{+} & 102 & 118 \\ \mathrm{NH}_{4}^{+} & 98 & 79 \\ \mathrm{Ca}^{2+} & 102 & 63 \\ \mathrm{Cu}^{2+} & 54 & \text { ND } \\ \mathrm{Mn}^{2+} & 10 & \text { ND } \\ \mathrm{Mg}^{2+} & 110 & 107 \\ \mathrm{Zn}^{2+} & 0 & \text { ND } \\ \mathrm{Fe}^{2+} & 104 & \text { ND }\end{array}$

ND, Not determined.

highest final cell yield were observed at this temperature. At $30^{\circ} \mathrm{C}$, only cocci were present and growth reached only $5 \mathrm{OD}_{650}$ units.

Effect of heating on the SMTPC of crude extracts. The demethiolase activity of crude extracts was reduced by $50 \%$ after heating at $30^{\circ} \mathrm{C}, 35^{\circ} \mathrm{C}$ and $45^{\circ} \mathrm{C}$ for $41 \mathrm{~min}, 9 \mathrm{~min}$ and $1 \mathrm{~min}$, respectively. The apparent activation energy, calculated from an Arrhenius plot, was $251 \mathrm{~kJ} \mathrm{~mol}^{-1}$.

Effect of metal ions. Only $\mathrm{Na}^{+}$and $\mathrm{K}^{+}$(to a lesser extent) stimulated methanethiol production by whole cells (Table 3). No stimulation of activity was observed with a dialysed crude extract; $\mathrm{Zn}^{2+}$ and $\mathrm{Mn}^{2+}$ strongly inhibited the activity and $\mathrm{Cu}^{2+}$ reduced it by $50 \%$.

The sMTPC of both cells and crude extracts was maximal when the $\mathrm{Na}^{+}$concentration in the culture medium was $1 \mathrm{M}$ (Fig. 3); this maximal activity was also observed in crude extracts with $0.5 \mathrm{M}-\mathrm{Na}^{+}$in the medium. The rate of transport of $\mathrm{L}-$-methionine by non-proliferating cells increased 12-fold when $\mathrm{Na}^{+}$was added to the suspension buffer at a concentration of $10 \mathrm{mM}$. 


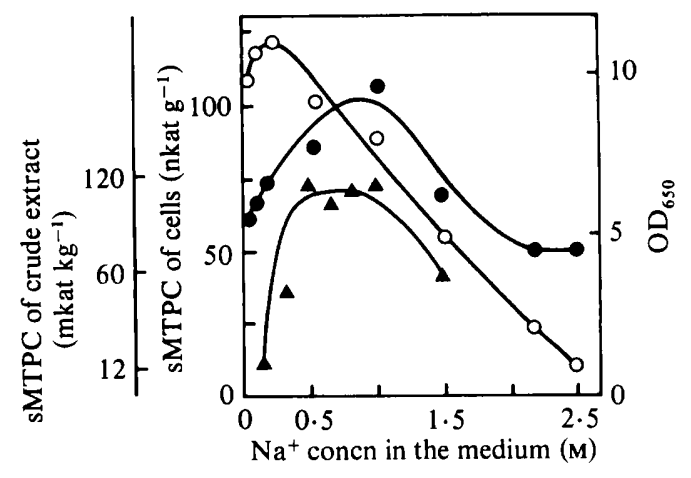

Fig. 3. Effect of $\mathrm{Na}^{+}$concentration in NID + L-methionine on the SMTPC of the cells (O), sMTPC of crude extract $(\triangle)$ and the maximal $\mathrm{OD}_{650}(\mathrm{O})$ of $B$. linens $\mathrm{CNRZ} 918$ at $26^{\circ} \mathrm{C}$.

The growth increase was maximal with $0.17 \mathrm{M}-\mathrm{Na}^{+}$in the culture medium, explaining the choice of this concentration for NID medium (Fig. 3). Above $1 \mathrm{M}-\mathrm{Na}^{+}$, growth inhibition was marked but not total, even at $2.5 \mathrm{M}-\mathrm{Na}^{+}$. Cell morphology did not change as a function of $\mathrm{Na}^{+}$ concentration. The same correlations were observed between $\mathrm{OD}_{650}$, number of cells dry weight at all $\mathrm{Na}^{+}$concentrations in the medium, indicating internal consistency.

\section{DISCUSSION}

The use of a non-inducing medium has enabled us to show that L-methionine is required to obtain significant methanethiol production by $B$. linens CNRZ 918. L-Methionine did not induce its own transport, which appeared to be constitutive, but it did induce the L-methionine$\gamma$-demethiolase. In a complex medium, it is undoubtedly free L-methionine, or L-methionine in the form of peptides included in the various components, which induces the L-methionine- $\gamma$ demethiolase in the absence of added methionine (Ferchichi et al., 1985).

The induction of one or several enzymes and permeases involved in methanethiol production has been described in Achromobacter starkeyi (Ruiz-Herrera \& Starkey, 1970), Pseudomonas ovalis (Tanaka et al., 1977) and Pseudomonas fluorescens UK1 (Laakso, 1979). In contrast, the system present in fungi is constitutive and active only on D-methionine (Ruiz-Herrera \& Starkey, 1969). Among the inducers we found effective for $B$. linens, D-methionine, which acted as a weak inducer (if free of $L$-methionine), was not a substrate for demethiolation by resting cells or crude extracts. The absence of methanethiol production from $D$-methionine indicates a lack of a methionine racemase in $B$. linens CNRZ 918. Such a racemase has been found in Pseudomonas sp. (Kallio \& Larson, 1955). Certain L-methionine-containing peptides were better inducers and substrates for whole cells than L-methionine itself. The most probable explanation for this is their better cell penetration, as has been shown for glycine and leucine in Streptococcus lactis (Rice et al., 1978). Peptide entry into whole cells seems to be followed or accompanied by hydrolysis. Crude soluble cell extracts could not demethiolate the same peptides. This might indicate that the peptidases were membrane-bound, or were destroyed during cell breakage or not active under conditions of assay. The intracellular L-methionine concentration thus probably plays an important role in the degree of induction, the more rapid entry of peptides leading to a higher internal concentration of the amino acid.

The extent of growth of $B$. linens CNRZ 918 in NID medium containing $7 \mathrm{mM}$-L-methionine was twice that in unsupplemented NID medium, showing that the amino acid is a limiting factor.

The $B$. linens demethiolase is a highly specific enzyme, since thiomethyl could be replaced by only thioethyl (L-ethionine). A shorter chain (S-methyl-L-cysteine) or a chain with a modified function (2-oxo-, 2-hyroxy) resulted in lower or undetectable demethiolation. 
Specific methanethiol production in cultures decreased as soon as the number of coccoid cells became significant although the transport rate by coccoid or rod cells was the same, invalidating our previous hypothesis (Ferchichi et al., 1985). Our present results indicate that this decreased production was probably related to the decreased concentration of inducer in the medium.

$B$. linens CNRZ 918 was isolated from the surface of a cheese, where it develops in the presence of $1-2 \% \mathrm{NaCl}$. Our results indicate that the transport of $\mathrm{L}$-methionine by this strain was sodium dependent, in contrast to its demethiolation. Such a dependence has been found in the case of threonine in Brevibacterium flavum (Shiio et al., 1973), a strain closely related to $B$. linens, and for other amino acids in Streptococcus lactis (Rice et al., 1978). Thus, the higher induction of L-methionine- $\gamma$-demethiolase obtained in NID + L-methionine when $\mathrm{Na}^{+}$was added is probably related to a higher intracellular concentration of $L$-methionine. Since the uptake of L-methionine was stimulated by extracellular $\mathrm{Na}^{+}$, the transport rate was probably the limiting step. This effect of $\mathrm{Na}^{+}$for such sodium-tolerant bacteria is certainly complex and requires more study.

The various conditions which influence demethiolation activity of $B$. linens could be useful in certain aspects of cheese technology.

We thank J. P. Accolas for providing the strain isolated by Dominique Melcion, Sylviane Roger and Christiane Degas for help in some techniques, D. Lebars for the amino acid analyses of samples, C. W. Lee for helpful criticism and suggestions during the drafting and P. Labbe for his continued interest in this work. M. Ferchichi was supported by a fellowship awarded by the Centre International des Etudiants Stagiaires (CIES), Paris. This work was partially supported by The Industry and Research Ministry, Biotechnology Contract 83 V0049.

\section{REFERENCES}

Esaki, N., Suzuki, T., Tanaka, H., Soda, K. \& RANDO, R. R. (1977). Deamination and $\gamma$-addition reactions of vinyl-glycine by L-methionine- $\gamma$-lyase. FEBS Letters 84, 309-312.

FerchichI, M., Hemme, D., Nardi, M. \& PaMBoUkdjian, N. (1985). Production of methanethiol from methionine by Brevibacterium linens CNRZ 918. Journal of General Microbiology 131, 715-723.

Ito, S., Nakamura, T. \& Eguchi, Y. (1976). Purification and characterization of methioninase from Pseudomonas putida. Journal of Biochemistry 79, 1263-1272.

KadOTA, H. \& IsHIDA, Y. (1972). Production of volatile sulfur compounds by microorganisms. Annual Review of Microbiology 26, 127-138.

Kallio, R. E. \& Larson, A. D. (1955). Methionine degradation by species of Pseudomonas. In Symposium on Amino Acid Metabolism, pp. 616-634. Edited by W. D. McElray \& H. B. Glass. Baltimore: Johns Hopkins Press.

Kreiss, W. \& Hession, C. (1973). Isolation and purification of L-methionine $\alpha$-deamino- $\gamma$-mercaptomethane-lyase (L-methioninase) from Clostridium sporogenes. Cancer Research 33, 1862-1865.

LAAKSO, S. (1979). Evidence of multiple demethiolation of methionine by a methionine utilizing mutant of Pseudomonas fluorescens UK1. FEMS Microbiology Letters 5, 407-409.

LAakso, S. \& LaUkKanen, N. (1982). The role of 2aminobutyrate in methionine utilization by Pseudomonas fluorescens UK1. FEMS Microbiology Letters 14, 107-111.

LAAKSO, S. \& NuRMIKKo, V. (1976). A spectrophotometric assay for demethiolating activity. Analytical Biochemistry 72, 600-605.
LAakso, S., Soderling, E. \& NuRmikKo, V. (1976). Methionine degradation by Pseudomonas fluorescens UK 1 and its methionine utilizing mutant. Journal of General Microbiology 94, 305-312.

LAW, B. A. (1984). Flavour development in cheeses. In Advances in the Microbiology and Biochemistry of Cheese and Fermented Milk, pp. 187-208. Edited by F. L. Davies \& B. A. Law. London \& New York: Elsevier Applied Science Publishers.

LAW, B. A. \& SHARPE, M. E. (1978). Formation of methanethiol by bacteria isolated from raw milk and Cheddar cheese. Journal of Dairy Research 45, 267275.

MERRICKs, D. L. \& SAlsbury, R. L. (1975). Dethiomethylation of methionine by an extract of rumen protozoa: general substrate specificity. Journal of Animal Science 42, 955-959.

Nakayama, T., Esaki, N., Lee, W. J., Tanaka, I., TANAKA, H. \& SODA, K. $(1984 a)$ ). Purification and properties of L-methionine- $\gamma$-lyase from Aeromonas sp. Agricultural and Biological Chemistry 9, 23672369.

Nakayama, T., Esaki, N., Sugie, K., Beresov, T. T., TANAKa, H. \& Soda, K. (1984b). Purification of L-methionine- $\gamma$-lyase. Analytical Biochemistry 138, 421-424.

Rice, G., Stewart, F. H. C., Hillier, A. J. \& Jago, G. R. (1978). The uptake of amino-acids and peptides by Streptococcus lactis. Journal of Dairy Research 45, 93-107.

RICHARD, J. (1984). Evolution de la flore microbienne à la surface des Camemberts fabriqués avec du lait cru. Le Lait 64, 496-520.

Ruiz-Herrera, J. \& Starkey, R. L. (1969). Dissimilation of methionine by demethiolase of Aspergillus species. Journal of Bacteriology 99, 766-770. 
Ruiz-Herrera, J. \& Starkey, R. L. (1970). Dissimilation of methionine by Achromobacter starkeyi. Journal of Bacteriology 104, 1286-1293.

Sharpe, M. E., LaW, B. A., Philipps, B. A. \& Pitcher, D. G. (1977). Methanethiol production by coryneform bacteria: strains from dairy and human skin sources and Brevibacterium linens. Journal of General Microbiology 101, 345-349.

Shilo, I., Miyajima, R. \& Kashima, N. (1973). $\mathrm{Na}^{+}$ dependent transport of threonine in Brevibacterium flavum. Journal of Biochemistry 73, 1185-1193.
Tanaka, H., Esaki, N., Yamamoto, T. \& Soda, K. (1976). Purification and properties of methioninase from Pseudomonas ovalis. FEBS Letters 66, 307-311.

Tanaka, H., EsaKi, N. \& Soda, K. (1977). Properties of L-methionine- $\gamma$-lyase from Pseudomonas ovalis. Biochemistry 16, 100-106.

Tanaka, H., Esaki, N. \& Soda, K. (1985). A versatile bacterial enzyme: L-methionine- $\gamma$-lyase. Enzyme and Microbial Technology 7, 530-537. 